\title{
Ceiling principle 'not needed' in DNA cases
}

Washington. DNA samples can be used for positive identification of crime suspects with greater certainty than has been assumed, according to a report released last week by the US National Academy of Sciences (NAS). As a result, the academy recommends that prosecutors should no longer use the so-called 'ceiling principle' to estimate the probability of a suspect being mistakenly identified by DNA evidence.

The 'ceiling principle' was recommended by an academy panel in 1992 as a means of estimating the chances of a mistaken identity in cases - quite common in the US legal system - where the suspect belongs to the same racial group as the perpetrator, but where information is scarce about the level of shared genetic information among members of that group.

But the new report, prepared by a panel chaired by James Crow of the University of Wisconsin at Madison, abandons the 'ceiling principle'. It argues that, with better genetic information now available about different racial groups, prosecutors should estimate the chances of mistaken identity by more direct and less conservative means.

Crow says that the main reason for the change is "the great abundance" of data now available about different genetic populations. The panel's report states that the technology for DNA profiling, and the methods for estimating frequencies and related statistics, "have progressed to the point where the reliability and validity of properly collected and analysed DNA data should not be in doubt".

The academy agreed to take a new look at the role of DNA in legal proceedings at the request of the Federal Bureau of Investigation (FBI) - a move that prompted some scientists to complain that the academy's neutrality was being compromised (see Nature 367, 101; 1996).

The FBI had asked for the new study because it thought that the application of the 'ceiling principle' in US courts was occasionally leading to wrongful and unnecessary

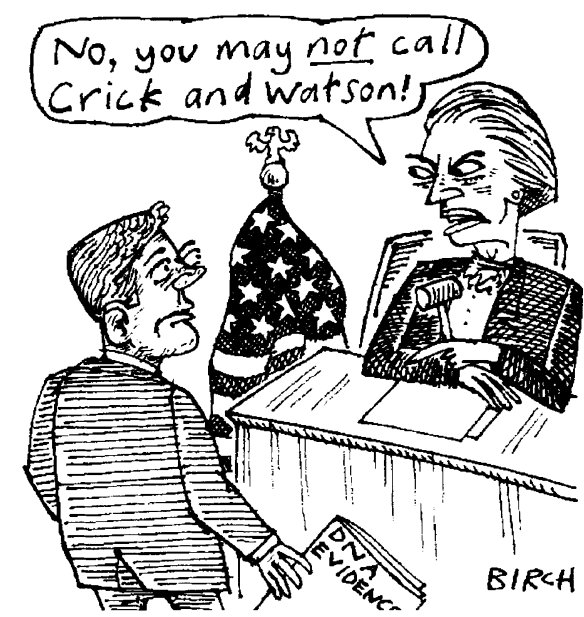

acquittals. The report was paid for by the National Institute of Justice - a sister agency of the FBI in the Department of Justice - and other government agencies.

According to David Kaye, a panel member and professor of law at Arizona State University, in typical cases where the 'ceiling principle' has been employed, it might suggest a possibility of an error of 1 in 10,000 , whereas a direct calculation would suggest a chance of only one in a million. In some case, defence lawyers have been able to convince juries that the former statistic constitutes cause for reasonable doubt in reaching verdict.

The academy panel also calls for laboratories analysing DNA samples to "adhere to high quality standards" and to "make every effort to be accredited for DNA work". It says that "whenever feasible, forensic samples should be divided into two or more parts", so that the second sample can be independently analysed.

Critics of the report expressed disappointment not so much with the abandon-

ment of the ceiling principle - which they had expected - but with what they said was the weakness of the recommended provisions for imposing quality requirements on DNA laboratories and allowing for duplicate testing.

"I'm unhappy with their unwillingness to demand quality" from the laboratories, says Richard Lewontin, a population geneticist at Harvard University in Cambridge, Massachusetts, who had been strongly critical of the terms of reference for the new study. He says the requirement to divide the sample is of no value to most US defendants in serious criminal cases, as their public defenders have no money to buy a second test.

Panel members said that questions about the reliability of the laboratories analysing DNA samples will be dealt with more fully by an independent Laboratory Advisory Board recently established by the FBI under the chairmanship of Joshua Lederberg, the Nobel prizewinner and former president of Rockefeller University in New York.

Colin Macilwain

\section{Group plans boost to German biotech}

Munich. A new technology advisory group, established by the German Chancellor, Helmut Kohl, to suggest ways of improving the commercial exploitation of biotechnology, set itself a tough deadline this week when it promised to produce its report by early autumn, rather than by December, as Kohl had requested.

The group is only the second Technolo gierat to have been established since Kohl created the concept two years ago. $\mathrm{He}$ identified biotechnology as an important topic for his technology advisers because of awareness by German politicians that Germany is missing an opportunity to profit from its industrial potential.

Germany's problems with biotechnology stem mainly from a cultural aversion to genetic engineering (known as 'gene technology'), which has led to biotechnological research and development being hindered by strict and bureaucratic legislation, as well as to relative underfunding.

Jürgen Rüttgers, the research minister, has been addressing the problems. New research programmes in biotechnology, for example, including involvement in the Human Genome Programme, have been launched in the past year by his ministry, which has also set up a group to investigate the general and legislative environment for research. Rüttgers has also said that biotechnology will be protected from the new cuts imposed on the ministry as part of an emergency budget being debated in parliament.
According to Detlev Ganten, director of the Max Delbrück centre for Molecular Medicine in Berlin, and a member of the new Technologierat, the group does not intend to come up with any dramatic proposals, but will analyse recognised problems in detail, propose priorities and make other recommendations. He sees its major role as providing a 'kick-start' to a process already primed to take off.

At a four-hour meeting on 6 May, the Technologierat, which includes representatives from the academic, industrial and political worlds, set up three working groups. They will look at technology transfer and scientific progress, at the general and legislative environment for biotechnology and at public acceptance of biotechnology. According to Ganten, the mood of the group was uniformly positive. For the first time, he says, industrialists appeared ready to believe that politicians were genuinely committed to improving their situation.

The Technologierat's recommendations are likely to have considerable influence. The report of the first such group, set up last year to look at multimedia and information technology, was completed last December, and many of its recommendations are already being put into practice. But changing public opinion is a forbidding task, and the government may also find it difficult to provide the increased funding which the Technologierat is likely to recommend.

Alison Abbott 